\title{
Production and analysis of volatile flavor compounds in sweet fermented rice (Khao Mak)
}

\author{
Jittimon Wongsa ${ }^{1, *}$,Vilai Rungsardthong ${ }^{2}$, and Tamaki Yasutomo ${ }^{3}$ \\ ${ }^{1}$ Department of Agricultural Engineering for Industry, Faculty of Industrial Technology and Management, \\ King Mongkut's University of Technology North Bangkok Prachinburi Campus, Prachinburi, Thailand \\ ${ }^{2}$ Department of Agro-Industrial, Food and Environmental Technology, Faculty of Applied Science, Food and Agro-Industry \\ Research Center, King Mongkut's University of Technology North Bangkok, Bangkok, Thailand \\ ${ }^{3}$ Department of Bioresource Technology, National Institute of Technology, Okinawa National College of Technology, \\ Okinawa, Japan
}

\begin{abstract}
Khao Mak is a sweet fermented rice-based dessert with a unique flavor profile commonly found throughout Thailand. The traditional starter culture (Look Pang) contains yeast, mold and herbs, which is used to ferment cooked glutinous rice. This research studied production of Khao Mak which resulted in volatile flavor compounds that were affected by rice varieties, including white glutinous rice (Kor Khor 6), Japanese rice (Hitomebore) and black glutinous rice (Kam Doi and Leum Phua). Total soluble solids (TSS) as degree Brix, $\mathrm{pH}$, and alcohol concentrations were measured daily during the fermentation period. Volatile flavor compounds were separated and identified by gas chromatography mass spectrometry (GC-MS). At the end of the fermentation, samples had $\mathrm{pH}$ ranging from $3.91 \pm 0.16$ to $4.30 \pm 0.09$, total soluble solids of $32.65 \pm 1.65$ to $44.02 \pm 1.72^{\circ}$ Brix, and alcohol concentrations between $0.33 \pm 0.03$ and $0.38 \pm 0.03 \%(\mathrm{v} / \mathrm{v})$. The potent odors associated with Khao Mak were alcohol, wine-like, whiskey-like, solvent-like, sweet and fruity. The major volatile compounds, which have stimulant flavor in Khao Mak, included 1-propanal, 1-propanol-2-methyl, 1-butanal-3-methyl and acetic acid ethyl ester. Among all rice varieties tested, the white glutinous rice produced Khao Mak containing the highest TSS, alcohol concentrations followed by Hitomebore rice and black glutinous rice, respectively.
\end{abstract}

\section{Introduction}

Fermented sweet rice called Khao Mak is a traditional sweet, low-alcoholic fermented product from Thai folk wisdom made mainly in the north-eastern and eastern provinces of Thailand. Apart from lactic acid and alcohol that give special flavours to Khao Mak, the fermented rice is also known for its health properties [1]. To produce Khao Mak, cooked glutinous rice and traditional fermentation starter were used in the process. The starter or Look Pang is a semi-circular starch ball that incorporates various fermentative biological species such as molds (Aspergillus species, Amylomyces species, Rhizopus species and Mucor species) and yeast (Saccharomyces cerevisiae, Issatchenkia species, Candida species, Saccharomycopsis species and Pichia species) [2]. In the production process of Look Pang, Thai herbs such as pepper, garlic, and galangal are added as antibacterial agents $[3,4]$.

After the fermentation, texture of the cooked rice became soft, agglutinated clumps that give mild alcoholic taste with lactic acid flavour [5]. Molds produce enzymes (e.g. $\alpha$-amylase, glucoamylase), which can hydrolyze raw starch in the glutinous rice and convert it into sugar. The process also yields other organic acids such as lactic acid [6]. After fermentation, Khao Mak is consumed as a sweet dessert dish without cooking.

Rice (Oryza sativa L.) is a predominant food and agricultural product of Thailand [7] which includes white rice varieties and pigmented rice varieties such as purple and black rice (e.g. Hom Nil, Rice Berry, Kam Doi, Leum Phua) and red rice (Sung Yod) [8].

Traditionally, Khoa Mak has been prepared from white glutinous rice. Pigmented rice which has been used as an ingredient for deserts and snacks is gaining more popularity due to its nutritional values [9]. When compared to normal white rice, black rice is found to harbour higher level of vitamin E and B, food fibres, and phytic acid. The rice also contains higher level of antioxidant activity when compared to red rice [10].

The production of Khao Mak with pigmented rice will make the product more nutritious. Also, the sweet aroma flavor of the product is also important for consumer's satisfaction.

In this study, Khao Mak will be produced from 4 varieties of rice. Highland black glutinous rice (Kam Doi), one of the aromatic and indigenous black sticky rice which is enriched with flavonoids, especially anthocyanins. Leum Phua is also a special variety of

\footnotetext{
* Corresponding author: jittimon.w@fitm.kmutnb.ac.th
} 
aromatic glutinous rice variety which has been reported to have very high antioxidant property. Thai white glutinous rice (Kor Khor 6) is a popular choice for producing Khao Mak because of its fragrance. Japanese rice (Hitomebore) is a special rice with a gentle flavor and extremely smooth texture. This research aims are to investigate volatile flavour compounds and its physical properties in Khao Mak that are affected by rice varieties.

\section{Experimental procedures}

\subsection{Materials}

Glutinous white rice (Kor Khor 6) and glutinous black rice (Kam Doi and Leum Phua) were all purchased from local market in Lampang, Thailand. Japanese rice (Hitomebore) was obtained from supermarket in Okinawa, Japan. Look Pang was supplied by Taonamchoke company which is located in Sisaket province, Thailand.

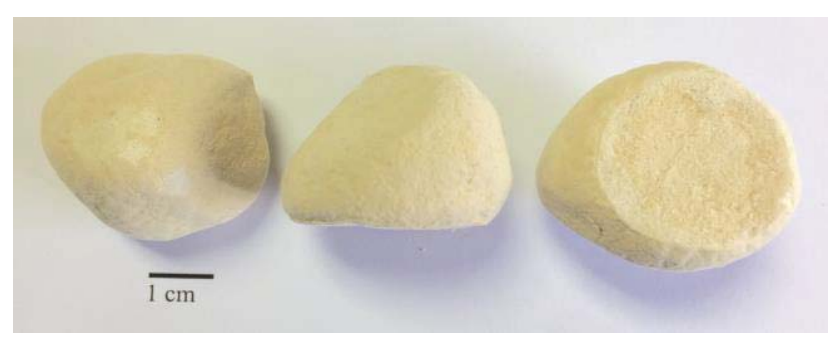

Fig. 1. Look Pang.

\subsection{Preparation of sweet fermented rice}

Sweet fermented rice was produced following the traditional process. Rice samples were submerged in water for 2 hours prior to being steamed in an autoclave at $121^{\circ} \mathrm{C}$ for 20 minutes. Cooked rice was washed with water and drained for 15 minutes to cool down at room temperature. Look Pang starter were crushed into a powder. The cooked rice $(300 \mathrm{~g})$ was treated with fermentative starter at $0.2 \mathrm{~g}$ per $100 \mathrm{~g}$ of rice in the glass container, then closed tightly and kept at $30^{\circ} \mathrm{C}$ for 3 days. The process flow chart of Khao Mak is shown in Fig. 2.

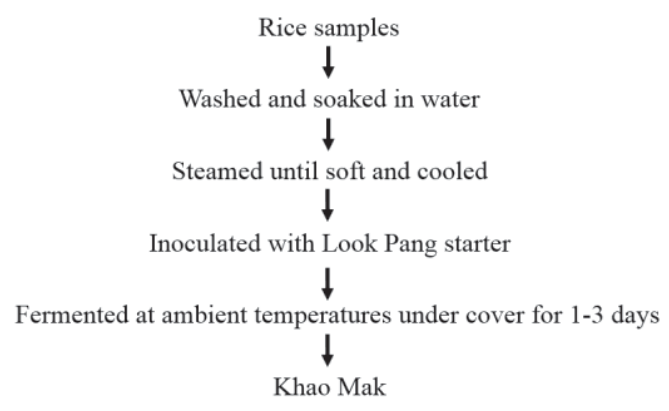

Fig. 2. Process for the production of Khao Mak.

\subsection{Total soluble solids, $\mathrm{pH}$ and alcohol concentration analysis}

Total soluble solid ( ${ }^{\circ}$ Brix) was measured in a small extracted solution sample of Khao Mak using a digital hand-held refractometer. The $\mathrm{pH}$ values were measured by using a $\mathrm{pH}$ meter. Alcohol content of samples was examined using a density/specific gravity meter.

\subsection{Assessment of DPPH radical scavenging's activity}

To assess DPPH radical scavenging's activity, samples were treated with 2,2-diphenyl-1-picrylhydrazyl at $0.1 \mathrm{mM}$ concentration and kept at room temperature, in the absence of light for 30 minutes. Spectrophotometer was used to measure level of absorbance at $517 \mathrm{~nm}$ [6] and percentage of the above said activities were measured and calculated by using the following formula;

$$
\text { Scavenging activity }(\%)=\left[\left(A_{0}-A_{l}\right) / A_{0}\right] \times 100
$$

$\mathrm{A}_{0}=$ the absorbance of control reaction

$\mathrm{A}_{1}=$ the absorbance of test compound

Interpolation of linear regression analysis was used to attain a concentration that inhibit half of the activity $\left(\mathrm{IC}_{50}\right)$

\subsection{Volatile Compound Analysis}

Khao Mak sample was extracted and then centrifuged at $3000 \mathrm{rpm}$ for $10 \mathrm{~min}$. Once the phases had been separated, the supernatant liquid phase was prepared for analysis of volatile compounds and n-amyl alcohol was used directly as internal standard. In brief, $1.0 \mathrm{~mL}$ of the sample and $1.0 \mathrm{~mL}$ of n-amyl alcohol were pipetted into a $20 \mathrm{~mL}$ chromatography headspace vial. The vial was sealed with aluminium crimp cap PTFE/ Butyl rubber septum, vortexed and placed in the headspace autosampler system (TurboMatrix 110, PerkinElmer, USA). The headspace gas was analyzed by Shimadzu GCMS QP2010 Ultra (Shimadzu Corporation, Tokyo, Japan) with a Stabilwax column; $60 \mathrm{~m} \times 0.25 \mathrm{~mm}$ i.d. $\times 0.50$ $\mu \mathrm{m}$ film thickness (Restek, USA). Temperatures program used were as following: $60^{\circ} \mathrm{C}$ hold for $1 \mathrm{~min}$, 60 to $200^{\circ} \mathrm{C}$ hold for $7 \mathrm{~min}$ and $200^{\circ} \mathrm{C}$ hold for $1 \mathrm{~min}$.

\section{Results and discussion}

The characteristics of Khao Mak samples depended on the varieties of rice. Figure 3 illustrates changing $\mathrm{pH}$ level of each rice samples which were used in this 7 days experiments. The samples from white glutinous rice (Kor Khor 6) on the $3^{\text {rd }}$ day of the fermentation were sweet acidic taste at the $\mathrm{pH}$ of $4.30 \pm 0.12$. Similar results were observed from the experiments which indicated that, after the first day of fermentation, Khao Mak's pH was $6.45 \pm 0.20$ before abruptly dropped to $3.17 \pm 0.16$ to $4.10 \pm 0.09$ after day 1 - 3 of fermentations. 
Khao Mak fermentation system converted monosaccharide in starch to ethyl alcohol and acids by using yeast and mold activities [4].

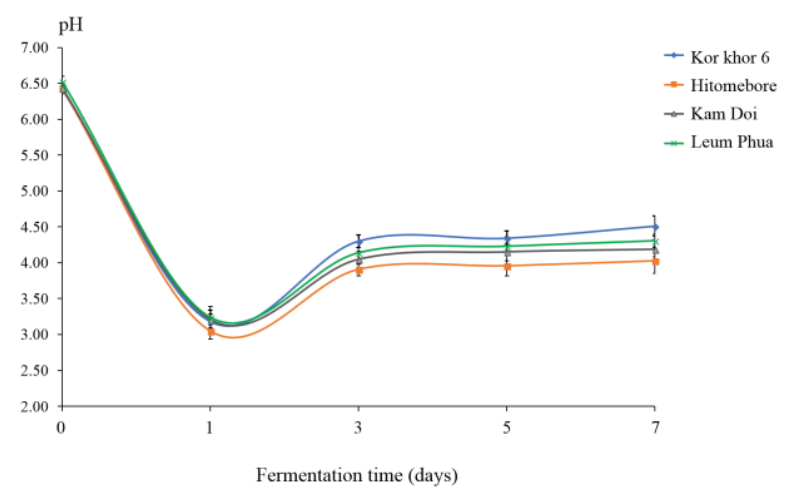

Fig. 3. Change of $\mathrm{pH}$ values in Khao Mak during fermentation.

Figure 4 shows levels of alcohol contents produced by the fermentation for which white glutinous rice exhibited high alcohol content. Khao Mak's alcohol level was at $0 \%$ on the first day of fermentation before sharply rose to approximately $0.35 \pm 0.03 \%$ on the $3^{\text {rd }}$ day and continued to increase until the end of the fermentation period. All treatments were exhibited similar trend, but with higher contents found in glutinous white rice more than that of black rice.

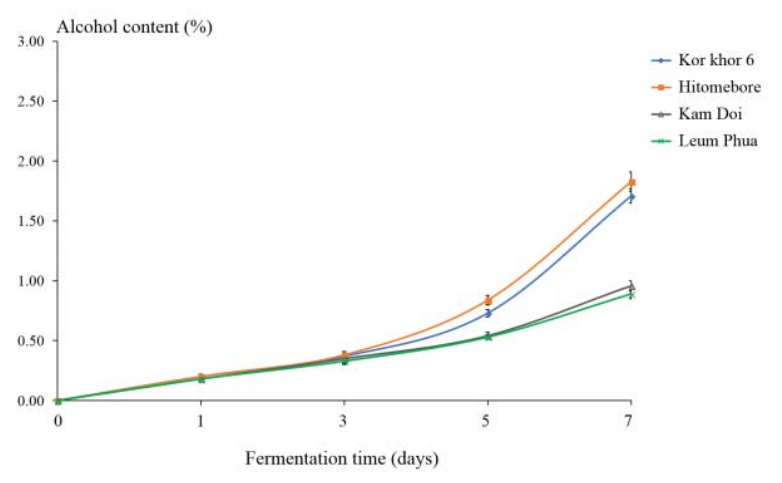

Fig. 4. Alcohol content of Khao Mak during fermentation.

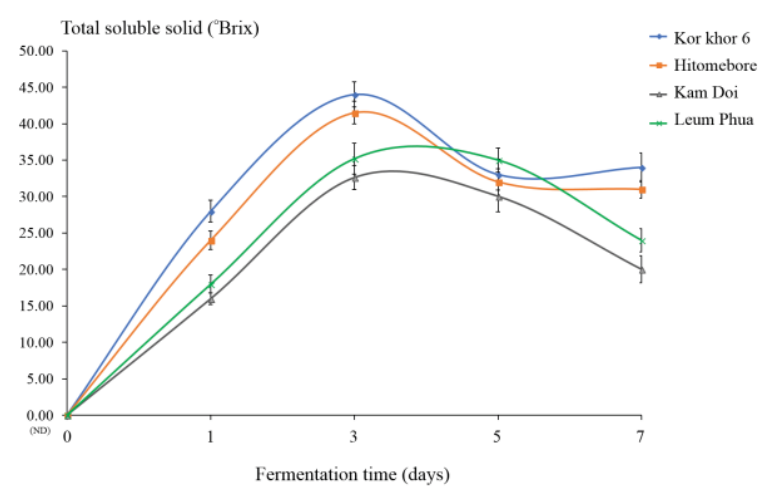

Fig. 5. Total soluble solid of Khao Mak during fermentation.
Figure 5 showed changes of Khao Mak's soluble solid during 7 days of fermentation. Total soluble solids content of all samples increased rapidly around $32.60 \pm 2.14$ to $44.05 \pm 1.72^{\circ}$ Brix after the fermentation started. Starch hydrolysis by mold resulted in increased sugar [11]. However, after the $4^{\text {th }}$ day, Khao Mak's total soluble solid were fluctuated and decreased.

In Figure 6, Khao Mak produced from black glutinous rice (Kam Doi and Leum Phua) gave the strongest free radical scavenging activity with the $\mathrm{IC}_{50}$ value of $43.40 \pm 2.42 \mathrm{mg} / \mathrm{mL}$ and $32.26 \pm 1.65 \mathrm{mg} / \mathrm{mL}$, respectively. Sangkitikomon et al. [10] suggested that black rice's anthocyanin performs higher antioxidant activity than other rice varieties.

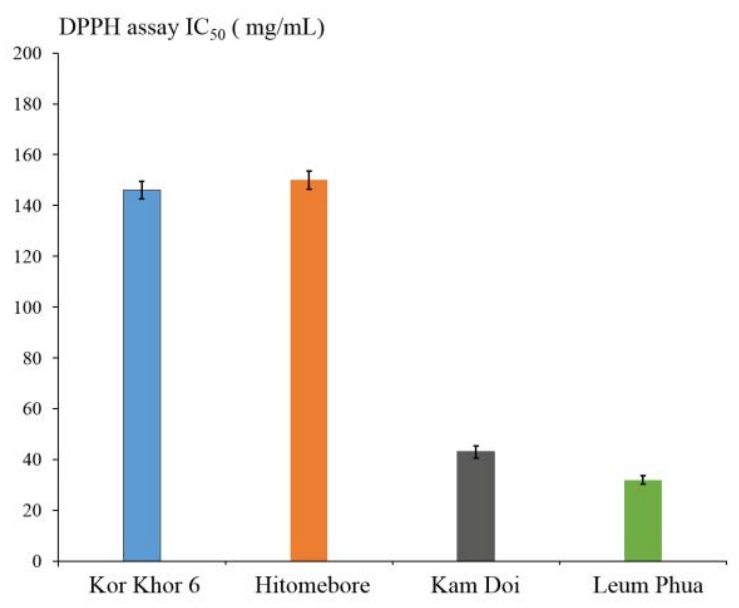

Fig. 6. DPPH radical scavenging activity $\mathrm{IC}_{50}$ of Khao Mak.

Volatile compounds in Khao Mak samples with various rice varieties were studied using gas chromatography mass spectrometry. Volatile compounds which shown as compound identification was attained from analysis of the provided qualitative data.

Four volatile compounds were commonly found in all samples (Table 1); acetic acid ethyl ester, 1-propanol, 1-propanol-2-methyl and 1-butanal-3-methyl. These compounds (1-propanol, 1-propanol-2-methyl and 1-butanal-3-methyl) also found in Thai rice wine (Sato and $\mathrm{Ou}$ product) $[12,13]$. The concentration of volatile compounds in black glutinous rice were higher than white rice fermented samples. This might be due to the difference of their initial nitrogen concentration (correlation with protein content) of raw material. Amino acid metabolism serves as an important factor that facilitates volatile compound productions in food and alcoholic beverages [12]. Khao Mak fermented with Luem Phua rice contained higher concentration of 1-propanol $(118.851 \pm 0.263 \mu \mathrm{g} / \mathrm{mL})$ and 1-propanol-2methyl $(19.005 \pm 0.095 \mu \mathrm{g} / \mathrm{mL})$ compared with other samples. 
Table 1. Volatile flavor compounds in Khao Mak analysed by GC-MS

\begin{tabular}{|c|c|c|c|c|c|c|}
\hline \multirow{2}{*}{ Compounds } & \multirow{2}{*}{ RT } & \multicolumn{4}{|c|}{ Concentration $(\mu \mathrm{g} / \mathrm{mL})$} & \multirow{2}{*}{$\begin{array}{c}\text { Odor } \\
\text { Descriptors } \\
\text { [Ref.] }\end{array}$} \\
\hline & & $\begin{array}{c}\text { Kor } \\
\text { khor } 6\end{array}$ & $\begin{array}{c}\text { Hitome } \\
\text { bore }\end{array}$ & $\begin{array}{c}\text { Kam } \\
\text { Doi }\end{array}$ & $\begin{array}{c}\text { Luem } \\
\text { Phua }\end{array}$ & \\
\hline $\begin{array}{l}\text { Acetic acid, } \\
\text { ethyl ester }\end{array}$ & 6.88 & $\begin{array}{c}0.650 \\
(0.020)\end{array}$ & $\begin{array}{c}4.050 \\
(0.025)\end{array}$ & $\begin{array}{c}0.897 \\
(0.012)\end{array}$ & $\begin{array}{c}0.924 \\
(0.008)\end{array}$ & $\begin{array}{l}\text { Pungent, } \\
\text { Sour, } \\
\text { Vinegar [13] }\end{array}$ \\
\hline 1-propanol & 10.07 & $\begin{array}{l}10.122 \\
(0.135)\end{array}$ & $\begin{array}{l}14.176 \\
(0.118)\end{array}$ & $\begin{array}{l}63.966 \\
(0.205)\end{array}$ & $\begin{array}{l}118.851 \\
(0.263)\end{array}$ & $\begin{array}{l}\text { Solvent [13] } \\
\text { Alcohol, } \\
\text { Fruity [14] }\end{array}$ \\
\hline $\begin{array}{l}\text { 1-propanol- } \\
\text { 2-methyl }\end{array}$ & 11.48 & $\begin{array}{c}6.278 \\
(0.091)\end{array}$ & $\begin{array}{c}7.193 \\
(0.046)\end{array}$ & $\begin{array}{l}10.810 \\
(0.150)\end{array}$ & $\begin{array}{l}19.005 \\
(0.095)\end{array}$ & $\begin{array}{l}\text { Alcohol, } \\
\text { Wine [14] } \\
\text { Solvent }[15]\end{array}$ \\
\hline $\begin{array}{l}\text { 1-butanol- } \\
\text { 3-methyl- } \\
\text { acetate }\end{array}$ & 13.12 & $\begin{array}{c}0.005 \\
(0.002)\end{array}$ & $\begin{array}{c}0.036 \\
(0.007)\end{array}$ & ND & $\begin{array}{c}0.010 \\
(0.004)\end{array}$ & $\begin{array}{l}\text { Solvent [12] } \\
\text { Fruity, } \\
\text { Malty [16] }\end{array}$ \\
\hline $\begin{array}{l}\text { 1-butanal- } \\
\text { 3-methyl }\end{array}$ & 15.06 & $\begin{array}{c}4.709 \\
(0.015)\end{array}$ & $\begin{array}{c}4.695 \\
(0.060)\end{array}$ & $\begin{array}{c}5.719 \\
(0.066)\end{array}$ & $\begin{array}{c}8.121 \\
(0.085)\end{array}$ & $\begin{array}{l}\text { Solvent [12] } \\
\text { Wine-like, } \\
\text { Sweet [17] }\end{array}$ \\
\hline $\begin{array}{l}\text { Hexanoic acid, } \\
\text { ethyl ester }\end{array}$ & 16.38 & $\begin{array}{c}0.023 \\
(0.008)\end{array}$ & $\begin{array}{c}0.007 \\
(0.003)\end{array}$ & $\begin{array}{c}0.024 \\
(0.010)\end{array}$ & ND & $\begin{array}{l}\text { Sour [16] } \\
\text { Sweat [14] }\end{array}$ \\
\hline 1-pentanal & 16.37 & $\begin{array}{c}1.050 \\
(0.000)\end{array}$ & $\begin{array}{c}1.050 \\
(0.000)\end{array}$ & $\begin{array}{c}1.050 \\
(0.000)\end{array}$ & $\begin{array}{c}1.050 \\
(0.000)\end{array}$ & $\begin{array}{l}\text { Whiskey-like, } \\
\text { Solvent [13] }\end{array}$ \\
\hline $\begin{array}{l}\text { Octanoic acid, } \\
\text { ethyl ester }\end{array}$ & 21.39 & $\begin{array}{c}0.005 \\
(0.004)\end{array}$ & $\begin{array}{c}0.014 \\
(0.009)\end{array}$ & ND & ND & $\begin{array}{l}\text { Sweat, } \\
\text { Cheese [14] }\end{array}$ \\
\hline
\end{tabular}

ND: Not detected

The numbers in brackets indicates the standard deviations.

\section{Conclusion}

Various rice, including glutinous white rice (Kor Khor 6), glutinous black rice (Kam Doi and Leum Phua) and Japanese white rice (Hitomebore), were fermented with Look Pang for volatile flavor compounds analysis. Highest content of TSS and alcohol were found in Khao Mak that was made from white rice. Aroma flavour of Khao Mak provided alcohol, solvent-like, wine-like, whiskey-like, sweet and fruity aromas. The volatile compound of 1-propanal, 1-propanol-2-methyl, 1-butanal-3-methyl and acetic acid ethyl ester was detected in the Khao Mak products.

Acknowledgment. This research was supported by National Institute of Technology, Okinawa National College of Technology, Japan and King Mongkut's University of Technology North Bangkok, Thailand under the Research Internship Program (June-July 2017).

\section{References}

1. S. Tanasupawat, K. Komagata, World J. Microbiol. Biotechnol. 11 p.253-256 (1995)

2. A. Taechavasonyoo, J. Thaniyavarn, C. Yompakdee, As. J. Food Ag-Ind. 6 p.24-38 (2013)
3. W. Tochampa, N. Jittrepotch, T. Kongbangkerd, K. Kraboun, K. Rojsuntornkitti, Int. Food Res. J. 18 p.239-248 (2011)

4. A. Manosroi, W. Ruksiriwanich, B. Kietthankorn, W. Manosroi, J. Manosroi, Food Res. Int. 44 p.2757-2765 (2011)

5. Y. Plaitho, K. Kangsadalampai, M. Sukprasansap, J. Med. Plants Res. 7,2 p.91-98 (2013)

6. N. Mongkontanawat, W. Lertnimitmongkol, J. Agri. Technol. 11,2 p.501-515 (2015)

7. S. Chanta, P. Prathepha, B. Jongdee, Indian J. Tradit. Know. 13,3 p.473-483 (2014)

8. P. Pramai, S.Jiamyangyuen, Songklanakarin J. Sci. Technol. 38,5 p.463-472 (2016)

9. K. Tananuwong, W. Tewaruth, LWT-Food Sci. Technol. 43 p.476-481 (2010)

10. V. Sangkitikomon, T. Tentumnou, A. Rodchanasasod, J. Nutr. 43,2 p.16-21 (2008)

11. A. Tongyai, S. Riebroy, S. Maneerat, N. Siriwong, S. Chulakarungka, Proceedings of the $50^{\text {th }}$ Kasetsart University Annual Conference (2012)

12. T. Amatayakul, N. Somsap, P. Rotsatchakul, KKU Res. J. 17,6 p.939-949 (2012)

13. P. Chuenchomrat, A. Assavanig, S. Lertsiri, Sci. Asia 34 p.199-206 (2008)

14. S. Cortés-Diéguez, R. Rodriguez-Solana, J. Manuel Domínguez, D. Emilia, J. Inst. Brew. 121 p. 628635 (2015)

15. T. E. Siebert, H. E. Smyth, D. L. Capone, C. Neuwöhner, C. H. Pardon, G. K. Skouroumounis, M. J. Herderich, M. A. Sefton, A. P. Pollnitz, Anal. Bioanal. Chem. 381 p.937-947 (2005)

16. S. Kaneko, K. Kumazawa, Biosci. Biotechnol. Biochem. 79,3 p.484-487 (2015)

17. E. Falqué, E. Fernández, D. Dubourdieu, Talanta. 54, p.271-281 (2001) 